Article

\title{
Expert-Led Securitization: The Case of the 2009 Pandemic in Denmark and Sweden
}

\author{
Olivier Rubin ${ }^{1, *}$ and Erik Bækkeskov ${ }^{2}$ \\ ${ }^{1}$ Department of Social Sciences and Business, Roskilde University, 4000 Roskilde, Denmark; E-Mail: rubin@ruc.dk \\ 2 School of Social and Political Sciences, The University of Melbourne, Parkville, VIC 3010, Australia; \\ E-Mail: erik.baekkeskov@unimelb.edu.au \\ * Corresponding author
}

Submitted: 4 March 2020 | Accepted: 10 May 2020 | Published: 10 December 2020

\begin{abstract}
This article goes beyond the study of speech acts to investigate the process of securitization during a health crisis. The article introduces the concept of 'expert-led securitization' to account for situations when experts dominate the administrative process that translates a securitizing speech act into extraordinary public policy. Expert-led securitization was particularly salient during the 2009 pandemic flu in Denmark and Sweden. Autonomous public health expert agencies led the national securitization processes, and these never included intense political battles or extensive public debates. In turn, the respective processes resulted in different policies: Sweden's main response to the pandemic was an extraordinary push to vaccinate its whole population, while Denmark's was a one-off offer of vaccination to about twenty percent of its people. Hence, the 2009 pandemic example illustrates the added value of investigating the administrative dynamics of securitization when seeking to understand differences in extraordinary policies.
\end{abstract}

\section{Keywords}

Copenhagen School; Denmark; evidence; experts; extraordinary responses; H1N1; health crisis; pandemic; securitization; Sweden

\section{Issue}

This article is part of the issue "The Politics of Disaster Governance" edited by Dorothea Hilhorst (Erasmus University Rotterdam, The Netherlands), Kees Boersma (Vrije Universiteit Amsterdam, The Netherlands) and Emmanuel Raju (University of Copenhagen, Denmark).

(C) 2020 by the authors; licensee Cogitatio (Lisbon, Portugal). This article is licensed under a Creative Commons Attribution 4.0 International License (CC BY).

\section{Introduction}

This article addresses a particular dimension of crisis governance, namely the elevation of a crisis to a security threat. Securitization of crises generates distinct governance processes as well as policies. Concretely, the article analyses the securitization of the $2009 \mathrm{H} 1 \mathrm{~N} 1$ pandemic and asks how two similar securitizing speech acts could nevertheless produce two very different health crisis responses in Denmark and Sweden.

The research on securitization has broadened out substantially during the last few decades both conceptually and empirically (Balzacq, 2005; Stritzel, 2007). Studies now routinely frame insecurity as something that can stem from multiple sources rather than solely from military threats and hostile states. Securitization can be applied to non-military threats such as migration (e.g., Robinson, 2017), climate change (e.g., Diez, Von Lucke, \& Wellmann, 2016) and health (Elbe, 2011; Enemark, 2017; Hanrieder \& Kreuder-Sonnen, 2014; Howell, 2014; Kittelsen, 2013; Roemer-Mahler \& Elbe, 2016). Many of these newer studies theorize securitization to include public administrative processes and policy decisions, and hence, extend empirical investigations beyond discourse analysis to include process tracing, content analysis, and even ethnographic research (Abraham, 2011; Enemark, 2017; Hameiri, 2014; Hanrieder \& Kreuder-Sonnen, 2014; Mclnnes \& 
Rushton, 2013; Roemer-Mahler \& Elbe, 2016; Watterson \& Kamradt-Scott, 2016).

This article contributes to this emerging literature in two ways. Conceptually, it reviews existing contributions and introduces the concept of expert-led securitization to describe a public administrative mechanism that impacts securitization processes. Expert-led securitization exhibits three distinct characteristics. First, 'initiation': In line with conventional securitization theory, securitization of threats is initiated at the political level through distinct 'speech acts.' Second, 'process': The ensuing securitization process is primarily driven by field experts working in key bureaucratic bodies rather than by politicians. Third, 'policy': Similar speech acts can be followed by different policies.

Empirically, the article investigates the national administrative dynamics of the 2009 flu (H1N1) pandemic securitization in two 'most-similar' countries, Denmark and Sweden, with different pandemic response policies. The article illuminates the role of the expert public health agencies' practices in securitization, emphasizing the significantly different processes in dealing with the health threat despite two otherwise similar socioeconomic environments.

The article is structured as follows. Firstly, it argues for analyzing securitization with a focus on administrative processes, particularly for infectious diseases. Secondly, it advances the concept of expert-led securitization, which includes three distinguishing characteristics. Thirdly, the article compares the securitization of the $2009 \mathrm{H} 1 \mathrm{~N} 1$ flu pandemic in Denmark and Sweden, finding that the three characteristics of expert-led securitization were strongly present in the cases. Notably, while conventional securitization theory suggests that all securitization is followed by extraordinary policies, the analysis here shows that focusing on expert leadership helps explain how extraordinary measures taken by governments really are.

\section{Securitization Processes}

Political studies often turn to the Copenhagen School to understand securitization. Within the Copenhagen School framework, securitization is understood conventionally as the outcome of speech acts that position an issue as an existential threat (Buzan, Wæver, \& De Wilde, 1998; Wæver, 1995). This discursive act of securitization involves several steps. First, political leaders frame a particular issue as an existential threat. Second, this framing needs to be accepted by the relevant audience. Third, this acceptance suspends 'normal politics' by legitimizing extraordinary emergency measures (Balzacq, 2005; McDonald, 2008). Extraordinary measures include government authorities taking any action that they deem necessary to curb the threat, such as claiming additional budgetary resources, censoring information, launching military operations, and restraining civil liberties. The focus on speech acts has proven to be a potent analyti- cal tool for understanding the initiation of securitization, usually by political leaders in high-politics settings (international summits, speeches, parliamentary debates, and so on). Analyses of speech acts often illuminate when issues move from being normal to being framed as security threats. For conventional securitization theory, the discursive build-up and acceptance of an issue as a security threat is what constitutes the process of securitization. As Abraham (2011, p. 799) notes: "A speech act is the moment that securitization occurs."

In this article, however, we join the many scholars who have extended the process of securitization beyond speech acts to also encompass bureaucratic dynamics (Balzacq, 2010; Balzacq \& Guzzini, 2015; Hameiri, 2014; McDonald, 2008; McInnes \& Rushton, 2013; Stritzel, 2007). This 'process' approach has been particularly salient in analyses of non-military threats such as surges in migration, climate change, and public health crises. These studies have abandoned the exclusive focus on speech acts and audience acceptance to analyze what happens to policymaking after securitizing speech acts. Looking at securitization only as series of speech acts can exclude important administrative and policy implications that help constitute and provide meaning to securitization (McDonald, 2008). Stritzel (2007, p. 377) argues that "the speech act itself i.e., literarily a single security articulation at a particular point in time, will at best only very rarely explain the entire social process that follows from it." Thus, it should be clear that speech acts can influence the management of a threat and the process of securitization. However, it does not determine the process of securitization. While analyses of speech acts highlight whether the process of securitization has been initiated, analyses of administrative dynamics can uncover how securitization processes manifest themselves.

The founding scholars of Copenhagen School securitization theory were actually attentive to the existence of bureaucratic dynamics, although these remained theoretically underdeveloped and analytically underutilized at the time. One of the earliest and most prominent Copenhagen School works on securitization, Buzan et al.'s (1998) Security: A New Framework for Analysis, referred to a category of 'functional actors' that did not include the principal actors initiating the securitization process (the securitizing actors) but that nevertheless significantly influenced decisions in the field of security (Buzan et al., 1998). In the case of military security, these functional actors could be "subunits within the state that are of interest in military security terms either because of an ability to shape the military or foreign policy of the state or because they have the capability to take autonomous action" (Buzan et al., 1998, p. 36). But this important work of the Copenhagen School, together with many of the earlier Copenhagen School works (e.g., Buzan, 1997; Wæver, 1995), did not pursue this bureaucratic political perspective further. The functional actors were only referred to in passing on two occasions. A polluting company was described as a potential functional 
actor in the context of environmental security, and in the context of military security, potential functional actors were described as assassins, mercenary companies, defense bureaucracies and the arms industry. Hence, both conceptually and empirically, functional actors in the Copenhagen School appear to have been included somewhat cursorily. Studies interested in the bureaucratic dynamics of securitization, therefore, have turned to public administration and policy theory to gain other insights into securitization.

In the case comparison that we present, conventional securitization theory has difficulties explaining how similar speech acts and levels of acceptance can result in two different responses: In one country the response was arguably highly extraordinary while the response was far more in line with normal politics in the other. We posit that a securitization process perspective, which incorporates bureaucratic practices, better explains the diversity of policy outcomes.

\subsection{Securitization Processes in Cases of Pandemics}

Key studies have applied securitization theory to concrete cases of health threats in the form of infectious disease epidemics (Abraham, 2011; Bengtsson \& Rhinard, 2019; De Bengy Puyvallée \& Kittelsen, 2019; Enemark, 2017; Hameiri, 2014; Hanrieder \& Kreuder-Sonnen, 2014; Mclnnes \& Rushton, 2013; Roemer-Mahler \& Elbe, 2016; Watterson \& Kamradt-Scott, 2016). In line with the process approach to explaining securitization, these studies all show that administrative processes can have decisive impacts on securitization. An often-used example of successful securitization of a health threat is the unanimous UN Security Council resolution 1308 from 2000, which concluded that HIV/AIDS posed a risk to stability and security (e.g., Altman, 2003). On close inspection, however, McInnes and Rushton (2013) found that many states never implemented extraordinary measures against HIV/AIDS, and that administrative and policy implications differed substantially between countries despite all responding to the same act of securitization. Hameiri's (2014) study of Indonesian health security politics related to the H5N1 avian influenza in 2005 also underscored administrative processes, namely the Indonesian Ministry of Health's bureaucratic interest in halting a growing fragmentation of responsibility and leakage of funds to other state and nonstate agencies. In another study of H5N1 securitization, Curley and Herington (2011) found that the securitization in Vietnam and Indonesia was shaped by administrative processes rather than by peak-level speech acts. Applying a collective securitization approach to the study of the EU, Bengtsson and Rhinard 2019 similarly conclude that networks and bureaucratic actors played a key role in shaping the processes and responses to largescale transnational health threats. These studies and others (Enemark, 2017; Roemer-Mahler \& Elbe, 2016) show empirically that including the administrative level can matter when investigating securitization of public health issues. Yet missing from this literature are clear conceptual lessons drawn from the analyzed cases. Hence, we add to the conceptual understanding by identifying and characterizing a particular securitization process, namely expert-led securitization.

\subsection{Expert-Led Securitization}

Expert-led securitization occurs when experts dominate an administrative process that translates a securitizing speech act into extraordinary public policy. The concept of expert-led securitization builds on Elbe's important contribution referring to the 'medicalization of security' as well as the 'pharmaceuticalisation of security' (Elbe, 2011, 2012). Elbe (2011) traces the medicalization of security to three contemporary security practices: (i) Security issues are increasingly being framed in medical terms; (ii) medical and public health experts play a much greater role in security policies; and (iii) pharmacological interventions (rather than traditional military measures) play a key role in providing security. The concept of expert-led securitization simultaneously broadens and narrows the scope of Elbe's medicalization of security. It narrows the focus to increased roles of medical professionals without making grander claims about a redefinition in general of insecurity as a medical problem. It broadens the scope by identifying distinct phases of expert involvement in securitization processes and introducing a framework that extends beyond health issues.

To provide insights into the policymaking dynamics underlying expert-led securitization, we find inspiration in Kingdon's 'multiple streams framework' from 1984 (Kingdon, 2014). The framework conceptualizes policies as the result of couplings between three 'streams' with separate and independent dynamics and rules: (i) The problem recognition stream where issues that require attention are identified and effective solutions outlined; (ii) the policy/solution stream characterized by a 'policy primeval soup' where many policy solutions are continuously simmering but where a few manage to be turned into concrete policy ideas by invested key stakeholders; and (iii) the political stream that encompasses the motives and opportunities of policymakers to advocate for a particular policy idea (Kingdon, 2014). We use the framework's three streams as a loose typological frame to illustrate situations where experts can exercise control over the securitization process.

Securitizing speech acts-that is, the framing of a societal condition as an existential threat, and thus, elevating it on the national policy agenda-take place in the political stream. The securitization of a threat must figure prominently on the policy agenda to gain the attention of the desired audiences for acceptance and to merit extraordinary means. Eriksson (1999) rightly argues that "anyone may securitize an issue, but only a few put a securitized issue onto the governmental agenda" (p. 11). We are interested in this form of securitization, initiated 
by high-level politicians with the purpose of placing the issue on the political agenda.

Actors may continuously frame different conditions as existential threats, but the multiple streams approach suggests that more than successful framing is needed for these potential threats to rise on the policy agenda; to be accepted by the relevant audience; and to foster extraordinary policies that can effectively deal with the threats. Within the multiple streams framework, socalled policy entrepreneurs champion attention to specific problems, match them with possible solutions, and launch the resulting policies into the political approval process when there is a window of opportunity for doing so (Kingdon, 2014). In securitization processes, such policy entrepreneurs need not be political leaders. These policy entrepreneurs championing political attention to certain issues as well as particular courses of action can be situated in departments, agencies, or even bodies outside of national governments. Groundwork for securitizing specific threats does not depend on political leaders but their security framing is essential to elevate policy options into formal policymaking. In the multiple streams framework, much of that groundwork is located in the policy stream where departments, agencies, think tanks, university researchers, and others with ideas about what policies should be enacted develop and debate them in technical terms. And once the securitizing speech act has been delivered by senior leaders, the process of developing the extraordinary means for responding to securitized issues moves into specific policy enactment and implementation.

A distinctive insight of expert-led securitization is that the top-tier decision makers who initiate the securitization of a threat through their speech acts are not necessarily the same actors that dominate the subsequent policy process by defining the policy content. The reason is a policy vacuum that allows experts to define the contents of public policy, which is often particularly prominent in health threats (Eriksson, 1999). As described in some detail by Elbe (2011, p. 855), medical experts have "been granted enhanced powers for controlling and mitigating pandemic threats through existing institutions" allowing them to extend "their influence more deeply into the domains of foreign and security policy" (Elbe, 2011 , p. 862). Strong forces in the policy stream pull health experts into such policy processes and push politicians out. Public health agencies and departments of health involved in the administrative process of health threat securitization are not just populated by general bureaucrats with backgrounds in political science, economics, law, and similar degrees. Rather, public health agencies employ health practitioners and researchers (such as epidemiologists, virologists, and medical infectious disease specialist). The professional recruitment and organizational culture of most public health agencies differ from generalist agencies, and they enjoy considerable autonomous authority (Boswell, 2009). In addition, politicians are eager to delegate responsibility in situations of low political rewards but high political risks (Boin, McConnell, \& Hart, 2008; Hood, 2010; Moynihan, 2012). Health threats can be contentious political issues where the remedies (e.g., vaccinations, isolation, quarantines, and school closures) carry substantial political risks. Sweden's extensive vaccination campaign during the 2009 influenza, for example, was publicly questioned in subsequent years because the vaccinations had the unintended consequence of increasing the prevalence of narcolepsy in the population (World Health Organization, 2011). Politicians are often likely to be punished for mismanaging a health threat either by overreaching or underestimating the response (Baekkeskov \& Rubin, 2014; Boin et al., 2008; Rubin, 2020).

Thus, inspired by the multiple stream framework, three analytical stages of expert-led securitization can be identified, with implications for our cases:

First, initiation: Aligned with conventional Copenhagen School theory, securitization of a threat is initiated through speech acts by leading politicians. In the policy stream, experts can exercise control over policy contents in the process of securitization. However, experts are unlikely to be able to initiate securitization without active backing from key political actors. Concretely, therefore, the first step in a securitization process analysis is to apply the more conventional Copenhagen School theory to determine whether the securitization of a threat has been initiated through speech acts. Securitization of infectious disease threats, therefore, is initiated in the political stream by political leaders. For the 2009 H1N1 pandemic, this means that we should observe that the framing $2009 \mathrm{H} 1 \mathrm{~N} 1$ as a security threat was performed as speech acts by leading politicians.

Second, process: After securitizing speech acts, experts will be the primary drivers and administrators of the securitization processes. This implies that key securitization decisions can be traced back to experts. Once the securitization process has been initiated in the political stream, the question becomes who dominates the policy stream: do the political leaders insist on ownership over the policy process or is there room for the experts to encroach on this stream? The policy steam of securitization is dominated by experts from the problem stream rather than politicians from the political stream. Thus, securitization of infectious disease threats is processed in the policy stream, which in turn is populated almost entirely by public health expert organizations and individuals. Political leaders are not much invested in the policy process and there is ample room for the experts to manage the process. For the $2009 \mathrm{H} 1 \mathrm{~N} 1$ pandemic, this means that we should observe that policies and programs for combatting 2009 H1N1 were developed by public health agencies and experts, with minimal participation from politicians or other actors.

Third, policy: According to conventional Copenhagen School theory, one would expect similar speech acts would produce policies that are extraordinary. The central causal claim of Copenhagen School theory is that 
successful securitization leads to extraordinary policies. However, the policies that result from expert-driven processes may be substantially different. Similar securitization discourses and framings on the political level do not mean that all jurisdictions will enact the same policies and programs to combat that threat because the actual policy content is defined in the subsequent, expert-led processes. In politically led processes, the same political actors responsible for the securitizing speech acts also dominate the policy stream, which naturally leads to greater congruence between speech acts and actual policy outcomes. Similar securitization framings across countries would thus result in the same types of extraordinary means. Expert-led securitization adds an intermedia variable to the policy stream that distorts the causal mechanism between speech acts and policy because of their substantial and autonomous influence on policy. For the 2009 H1N1 pandemic, this means that we should be able to find different (extraordinary or not) policies subsequent to similar speech acts.

Table 1 below summarizes the three stages of expertled securitization.

\section{Expert-Led Securitization in Denmark and Sweden during the 2009 H1N1 Pandemic}

Drawing on the approach of expert-led securitization, the following analysis of the securitization processes in Denmark and Sweden is structured according to the three analytical stages developed previously: (i) Initiation of securitization by speech acts elevating pandemics to existential threats; (ii) expert involvement in processes of securitization in the two countries; and (iii) policies following from these two distinct processes of securitization. First, we briefly outline our research design.

\subsection{Most-Similar Case Design}

Denmark's and Sweden's responses to 2009 H1N1 are particularly useful to compare because these Scandinavian neighbors share many political and social characteristics. The countries are similarly situated in Northern Europe, which means that their populations are exposed in the same ways to fast-spreading infectious diseases such as influenza. Because of continu- ous traffic across the border between the two neighbors, such diseases can easily spread directly from one to the other. Denmark and Sweden are well known for sharing linguistic and cultural characteristics. In addition, their political and social policy systems are similar. Both are democracies with proportional representation ruled from one parliamentary chamber, often by multi-party coalitions. Neither had national or local elections during 2009 or early 2010, so pandemic response was not positioned to become an election issue. Both have welfare states of the Social Democratic variety that includes universal health care (Esping-Andersen, 2015), making them similarly capable of managing infectious disease cases. Both are very wealthy coordinated market economies (Hall \& Soskice, 2003), giving them similar financial capacity to purchase drugs and technologies to counter novel diseases. Hence, comparing these two countries controls a variety of factors that can plausibly explain variation in public policies against pandemic influenza (i.e., they are most-similar systems; Przeworski \& Teune, 1970). In turn, this means that, a priori, we could reasonably expect that the two countries would similarly securitize the same infectious disease event happening at the same time.

The present analysis uses primary data from newspaper articles, policy documents, and eight in-depth research interviews conducted with key Danish and Swedish officials involved in deciding their respective countries' 2009 H1N1 pandemic responses (see Box 1). The media articles were selected using print media databases (Retriever Research in Sweden and Infomedia in Denmark) through key search words such as 'H1N1' or 'swine flu.' The policy documents encompass internal and external evaluations, white papers, press releases and press briefing transcripts. Interviewees were identified through analyses of documents and reports on the 2009 H1N1 events and referrals from preliminary informational conversations and earlier interviews. Interviews were conducted and recorded in 2013, 2014, and 2019. They were structured and open-ended using the same interview guide for all, with adjustments only for the specific positions and formal roles during 2009 of the interviewees. Each interview lasted between one and two hours. Most interviews were conducted face to face, and one interview used here was conducted by telephone. Each interview was transcribed.

Table 1. Expert-led securitization stages.

\begin{tabular}{|c|c|}
\hline Securitization stages & Expert-led securitization \\
\hline Initiation & The threat is securitized through speech-acts on the political level. \\
\hline Process & $\begin{array}{l}\text { Experts define the contents of securitization, and other actors defer to expert judgments } \\
\text { and advice. }\end{array}$ \\
\hline Policies & $\begin{array}{l}\text { Dissimilar policies can follow from similar securitizing speech-acts across countries, due to } \\
\text { differences in expert advice and judgments. Notably, this means that policies may or may } \\
\text { not be extraordinary. }\end{array}$ \\
\hline
\end{tabular}


Box 1. List of interviewees.

1. Fisker, Jesper. 7 March 2014. Former Director of Sundhedsstyrelsen, Denmark.

2. Jensen, Ole A. 15 October 2013. Head of Administration, Statens Seruminstitut, Denmark.

3. Nielsen, Jacob A. 11 April 2014. Former Minister of Health for Denmark.

4. Mølbak, Kåre. 19 February 2019. Former State Epidemiologist, Statens Seruminstitut, Denmark.

5. Örtqvist, Åke. 5 September 2014. Medical Officer for Stockholm County, Sweden.

6. Pedersen, Nils S. 20 November 2013. Director of Statens Seruminstitut, Denmark.

7. Smith, Else. 12 November 2013. Former Head of the Infectious Diseases Unit, Sundhedsstyrelsen, Denmark.

8. Tegnell, Anders. 9 September 2014. Former Head of the Infectious Diseases Unit, Socialstyrelsen, Sweden.

\subsection{Initiation: How Pandemics and the 2009 H1N1 Were Elevated to Existential Threats}

The growing literature on securitization of infectious disease outbreaks and pandemics generally concludes that such events became securitized during the 2000s. Existing studies show this through a variety of methodological approaches and levels of analysis (Abraham, 2011; Davies, 2008; Elbe, 2009; KamradtScott \& Lee, 2011; McInnes \& Lee, 2006; Watterson \& Kamradt-Scott, 2016). Most notably, the 2007 World Health Organization annual health report characterized pandemic influenza as the most feared security threat facing the world (World Health Organization, 2007). There is also evidence that the $2009 \mathrm{H} 1 \mathrm{~N} 1$ influenza outbreak and subsequent pandemic was securitized through speech acts. Using the conventional Copenhagen School approach, Abraham (2011) shows that the $2009 \mathrm{H} 1 \mathrm{~N} 1$ pandemic was securitized through a global effort. Similarly, Kittelsen concludes that the threat was repeatedly framed in security terms within the EU, and that the H1N1 pandemic "reinforced the securitization process already underway" (Kittelsen, 2013, p. 232).

On 25 April 2009, the World Health Organization alerted the world at large about the outbreak by declaring a Public Health Emergency of International Concern (the first such declaration ever; Hanrieder \& KreuderSonnen, 2014), which is a formal declaration of an extraordinary event considered to constitute a public health risk. This was followed on 11 June 2009 by the World Health Organization's declaration that 2009 H1N1 now constituted a pandemic. The 2009 H1N1 outbreak and development into a pandemic specifically became the subject for speech acts by political leaders, combining alarm and reassurance.

Sweden's then Minister of Health and Aging Maria Larsson on 27 April broke off a visit to China to attend an emergency meeting of health ministers of the EU on the H1N1 outbreak and described that the relevant Swedish agencies were meeting continuously and that H1N1 was on the cabinet's daily agenda. Yet she em- phasized that "the Swedish people can feel safe knowing that Sweden has the highest preparedness" (Sveriges Television, 2009a, authors' translation). Similarly, reacting to the World Health Organization's pandemic declaration on 11 June 2009, Larsson underscored that response "is about planning so that the health care system works, so that the elder care system works, so that energy production works," but she also reassured Swedes that "nothing alarming has actually happened. Sweden has the situation under control" (Sveriges Television, 2009b, authors' translation).

Denmark also saw public reassurances in the midst moving to emergency measures. To illustrate, a Danish tabloid article headed "Danes Can Die in Their Thousands" reported that "doctors and authorities have begun a desperate race with time" including "a two and a half hour crisis meeting" of Denmark's Pandemic Group; yet the Minister of Health Jacob Axel Nielsen was also cited, offering reassurance that "there is nothing to fear" and "swine flu is no more dangerous than a summer flu, and there is medicine for one million Danes if it should be needed" (Barfoed, 2009, authors' translations). Indeed, Nielsen and others have revealed in subsequent research interviews that the government and its public health agencies deliberately sought to diffuse any sense of panic about $2009 \mathrm{H} 1 \mathrm{~N} 1$ through coordinated and calming public messages (Fisker interview, 2014; Nielsen interview, 2014).

The push to securitize pandemics in the new millennium had elevated outbreaks of novel influenzas to severe threats (Kittelsen, 2013; World Health Organization, 2007). The World Health Organization's declarations had raised alert levels, which national media in turn communicated to publics across the world. Such alerts signaled an imminent and potentially deadly threat to public safety. Hence, political leaders facing the 2009 H1N1 outbreak had to react publicly to them by acknowledging the potential severity of the new virus and engaging in emergency deliberations about response actions within public health agencies and departments. In public messages, national politicians were also reacting to the situation by communicating that government was in 
control, rather than enhancing the impression of impending doom. The combination of alarm and public reassurances thus elevated the $2009 \mathrm{H} 1 \mathrm{~N} 1$ outbreak to a crisis event with implications for public safety.

\subsection{Process: How National Experts Steered 2009 H1N1 Response Policymaking and Policies}

The previous section showed that in Sweden and Denmark, 2009 H1N1 was elevated to the status of a threat to public safety by securitization of pandemics generally in the years prior to 2009, global alerts and news about the outbreak and spread of a new H1N1 influenza strain during 2009 and reassuring public messages by senior elected officials in the wake of these developments. To understand how government action can follow from such issue elevation, this section traces the administrative processes involved in 2009 H1N1 response-making in Denmark and Sweden.

Like many other countries, the governments of Sweden and Denmark responded to the threat of a coming influenza pandemic by authoring national strategies for how to respond. While these national pandemic preparedness processes had several iterations starting around 2003, the Danish and Swedish strategies in place prior to the April $2009 \mathrm{H} 1 \mathrm{~N} 1$ outbreak were finalized in 2006 (Socialstyrelsen, 2006; Sundhedsstyrelsen, 2006). As detailed by Baekkeskov (2016a, 2016b), key ideas about the pandemic threat settled in these prepandemic preparations informed how national public health experts thought about the actual pandemic that unfolded from late April 2009. The preparations created a crucial difference between how Sweden and Denmark considered the pandemic threat, which was carried forward by the respective national public health experts into 2009 H1N1 response (Baekkeskov, 2016a, 2016b). In Denmark, pandemic flu was conceptualized primarily as 'a threat to lives,' and mostly those of people with preexisting health conditions (i.e., risk groups). In Sweden, pandemic flu was conceptualized as 'a threat to social continuity' (disruption to public health, workforce participation, businesses, social services, etc.). These different threat conceptions led to significantly different uses for vaccination (i.e., the ultimate measure against flu). The Danish plan focused on identifying the groups most at-risk of death and severe effects and directing available vaccines to these groups. The Swedish plan focused on limiting expected social disruptions by directing vaccines to at-risk groups as a first stage in vaccinating the whole population. These different expectations for what was still an unknown future event were made concrete as each country negotiated an 'advance purchase agreement' (finalised in 2006/2007) with the pharmaceutical company GSK for guaranteed deliveries of pandemic flu vaccine if the World Health Organization declared a full-scale pandemic (as happened on 11 June 2009). Denmark's advance purchase agreement secured vaccines for at most 42 percent of its popula- tion (Sundhedsstyrelsen, 2011). Sweden's advance purchase agreement secured vaccines for up to 100 percent of its population (Myndigheten för Samhällsskydd och Beredskap, 2011).

The first stage of the $2009 \mathrm{H} 1 \mathrm{~N} 1$ response by Danish and Swedish departments and agencies began on 25 April (Myndigheten för Samhällsskydd och Beredskap, 2011; Sundhedsstyrelsen, 2011). Each country's national board of health tasked specific units to set up new monitoring and epidemiological surveillance activities focused on H1N1. Within days of 25 April, each also began national-level deliberations about how to respond between various agencies and summoned experts (Mølbak interview, 2019; Smith interview, 2013; Tegnell interview, 2014). The national boards of health immediately ramped up emergency operations centers and similar facilities. Regular agency staff were seconded to these on a $24 / 7$ basis, including epidemiologists and virologists who could track how the outbreak spread as well as its public health implications. Hence, within Sweden's Socialstyrelsen and Smittskydsinstitutt, staff were immediately assigned to be on top of the H1N1 outbreak (Myndigheten för Samhällsskydd och Beredskap, 2011; Tegnell interview, 2014). For the same exact reasons and tasks, staff in Denmark's Sundhedsstyrelse and Statens Seruminstitut were mobilized (Mølbak interview, 2019; Smith interview, 2013; Sundhedsstyrelsen, 2011).

The second stage of the administrative response began when the World Health Organization declared on 11 June 2009 that the novel H1N1 outbreak had become a full-blown pandemic. In Denmark and Sweden, the public health agencies faced an extraordinary impact. Before 2009, both countries had signed contracts with GSK, a pharmaceuticals producer, for vaccines against pandemic flu (Jensen interview, 2013; Myndigheten för Samhällsskydd och Beredskap, 2011; Sundhedsstyrelsen, 2011). These Advance Purchase Agreements included terms that pandemic vaccine purchases would be triggered if the World Health Organization declared a full ('level 6') pandemic. Each set of decision-makers was contractually obliged to make a purchase order within few weeks of the pandemic declaration. This meant that Sweden and Denmark's respective governments had to decide and place a precise order of vaccines from GSK in the weeks following 11 June 2009.

Formally, political leaders were responsible for pandemic vaccine purchases in June 2009 and allocations of vaccines to population subgroups in subsequent months. However, close studies of Danish and Swedish 2009 H1N1 vaccination policymaking have shown that elected officials in both countries consistently and without exception followed the advice received from the national experts and agencies as they decided and approved policies (Baekkeskov, 2016a, 2016b; Baekkeskov \& Öberg, 2017). In Sweden, the national agencies were advising and coordinating actions across Sweden's 21 counties (mediated by the Swedish Association of Local Authorities and Regions), rather than through central 
state action. In practice, much of the decision-making about how to implement pandemic response depended on advice from the counties' Medical Officers (Mølbak interview, 2019; Myndigheten för Samhällsskydd och Beredskap, 2011; Tegnell interview, 2014; Örtqvist interview, 2014). These individual experts and officials made their own judgments about how to prioritize access to vaccination and other treatments. Hence, while all Swedes eventually gained access to pandemic flu vaccinations and through their primary care clinics, the timing of rollouts and details of who was prioritized could vary between the counties (Myndigheten för Samhällsskydd och Beredskap, 2011; Tegnell interview, 2014). In Denmark, formal policymaking was entirely national. Hence, Sundhedsstyrelsen's and Statens Seruminstitut's experts interacted with the Minister of Health, who had direct policy responsibility, as well as informing national politicians from the various political parties represented in the Danish parliament. Sundhedsstyrelsen, in consultation with Statens Seruminstitut experts on infectious diseases and vaccination protocols, managed Denmark's pandemic vaccine rollout and prioritization schedule (Pedersen interview, 2013; Smith interview, 2013).

Prior studies show that key ideas about pandemic threats and vaccination uses dominated expert thinking about 2009 H1N1 response. Despite intense months of sense-making and information gathering after the April outbreak, national expert guidance in each response stage closely followed the ideas about the pandemic threat and the uses of vaccination that had been settled during national pandemic planning (Baekkeskov, 2016b; Baekkeskov \& Öberg, 2017). Hence, in line with their preparations (previously described), Danish experts advised the national government to purchase vaccines for about 28 percent of the population, and subsequently to focus only on groups most at-risk of severe complications (Sundhedsstyrelsen, 2011). In contrast, but in line with their own preparations, Swedish experts advised county governments to purchase vaccines for everyone, and to roll out vaccination to the whole population (Myndigheten för Samhällsskydd och Beredskap, 2011). In turn, the respective governments followed and implemented their experts' advice without alteration - that is, formal authority gave way to epistemic dominance in the policy stream to create the respective Danish and Swedish responses and the differences between them. This delegation constitutes an important trait of expertled securitization.

In addition to the appointed experts' importance in response-making, key experts from the national public health agencies in Sweden and Denmark predominated in their respective national public debates about 2009 H1N1. Close comparisons of newspaper coverage of $2009 \mathrm{H} 1 \mathrm{~N} 1$ and related policy initiative in the two countries during 2009 shows this (Baekkeskov \& Öberg, 2017). For instance, 70 percent of the claims in the Swedish media about vaccination policy during the H1N1 pandemic came from experts and less than 10 percent could be traced back to politicians (the remaining claims were made by civil society organizations or journalists; Baekkeskov \& Öberg, 2017).

In sum, analysis of expert involvement in the securitization process suggests a high degree of participation and visibility in the decision-making process. Rather than politicians dominating policymaking when it came to the securitization process of transforming speech acts into concrete extraordinary policies, it appears that experts had a substantial influence on this process. In addition, such influence was not indirect and covert; rather, the public discourse openly recognized the health agencies as key players.

\subsection{Policy: Similar Speech Acts of Securitization Had Different Policy Outcomes}

Sweden and Denmark both took policy measures in the wake of speech acts that securitized 2009 H1N1. Both countries used information-based initiatives focusing on hand washing and other hygiene measures (Myndigheten för Samhällsskydd och Beredskap, 2011), and opened government stores of antiviral medication (Vilhelmsson \& Mulinari, 2018).

However, the countries took measures in different degrees. As described, the public discourse on Danish and Swedish responses to $2009 \mathrm{H} 1 \mathrm{~N} 1$ was dominated by a small handful of national experts. But while similarly influential, these expert sources carried very different messages in the two countries. Swedish experts emphasized the danger to all of society from the pandemic, and the need for everyone to participate by accepting vaccination (Baekkeskov \& Öberg, 2017). In contrast, their Danish counterparts emphasized that the pandemic only posed a danger to people with certain medical conditions, and that everyone without these conditions could rely on general hygiene and regular flu treatments (i.e., bedrest and plenty of fluids). Similarly, each country's critical policies, particularly on vaccinations, differed. Sweden's main policy response was intense and universal-a general vaccination campaign that developed in stages to include all residents (e.g., Myndigheten för Samhällsskydd och Beredskap, 2011). Denmark's main policy response was moderate and targeted-vaccination was offered only to highly at-risk groups (e.g., Sundhedsstyrelsen, 2011). Despite similar speech acts securitizing the pandemic, the subsequent process of securitization thus differed. That is, they exposed their respective populations to disease risk in substantively and significantly different ways.

Some scholars have criticized the conventional Copenhagen School for being ambiguous with regards what constitutes an extraordinary response, particularly in non-military contexts (Williams, 2015). However, it is safe to say that the Swedish response was significantly more extraordinary than the Danish in that Sweden mobilized society and attempted general mass vaccination 
while Denmark issued warnings to at-risk groups and attempted targeted vaccination. If the term 'extraordinary responses' in the context of health threats is to retain analytical value, then a previously unscheduled and nationwide vaccination campaign for all residents must be considered highly extraordinary. In contrast, offering vaccines to high-risk groups (something most countries do anyway in influenza season) is considerably less abnormal (though clearly extraordinary in the sense of being previously unscheduled). This significant variation in responses cannot be explained by considering speech acts in isolation. But as shown, accounts of the administrative process surrounding the securitizing speech acts is better equipped to explain variations in extraordinary policies.

Table 2 below summarizes the key empirical findings according to the three stages of expert-led securitization.

\section{Conclusion: Securitization through Initiating Speech Acts and Expert-Led Administrative Processes}

The Danish and Swedish cases of 2009 H1N1 influenza pandemic responses show the utility of investigating administrative processes to chart the policy dimensions of securitization. We see the importance of administrative practices for the securitization process in Denmark and Sweden during 2009. We see it in the details of how the pandemic was securitized in practice, as a semiautomated and technocratic process that linked pandemic planning and preparations made before anyone had heard of $2009 \mathrm{H} 1 \mathrm{~N} 1$. And we see it in the general deference by the elected politicians with formal power and responsibility to judgements developed at the World Health Organization and by national experts. Notably, Denmark and Sweden differed little in terms of how much they relied on administrative practices to securi- tize the 2009 H1N1 pandemic. Where the two administrative processes differed was in the core ideas that they relied on in order to formulate concrete responses to the securitization of the $2009 \mathrm{H} 1 \mathrm{~N} 1$ pandemic. This led to two very different policy responses where the Swedish was arguably highly extraordinary whereas the Danish response was far more in line with normal politics.

Understanding the practice of securitization, therefore, depends on more than study of speech acts by elected officials. This article has shown that if we want to understand both the elevation of an event to an existential threat and the development of extraordinary policies to counter the threat, analysis of the administrative processes that surround or follow such speech acts can be necessary. This argument appears even more relevant in the light of the plethora of extraordinary (and some not so extraordinary) policies that have been implemented in response to the Covid-19 pandemic. In the securitizing process, the roles and insights of key experts and expert agencies-in this case of biomedical and other disease experts organized in public health agencies-can be particularly powerful. While speech acts by the respective health ministers played a key role in elevating $2009 \mathrm{H} 1 \mathrm{~N} 1$ as a threat to public safety on the respective national agendas, this study shows that the actual response policies were differently extraordinary, which was largely determined by the key Swedish and Danish experts. Expertled securitization processes are thus capable of explaining securitization of public health issues and qualifying how extraordinary measures taken to mitigate them are.

\section{Postscript on Covid-19}

While this article was in review, the world experienced Covid-19, which is arguably the worst pandemic in a cen-

Table 2. Summary of findings supporting expert-led securitization during the 2009 pandemics.

\begin{tabular}{lll}
\hline Securitization stages & Expert-led securitization & The 2009 pandemic case-study \\
\hline Initiation & The threat is securitized through speech-acts & Pandemics had been increasingly securitized by \\
& in the political stream. & key actors up through the 2000s. \\
& The 2009 pandemic was framed by political \\
& leaders as a potential existential threat both \\
& internationally and in Denmark and Sweden.
\end{tabular}

Process

Experts define the contents of securitization, and other actors defer to expert judgments and advice.

Policies
Extraordinary but dissimilar policies can follow from similar speech-acts across countries, due to differences in expert advice and judgments.
The securitization administrative process was primarily driven by field experts working in key health agencies.

Politicians had limited engagement with the process, turning to the national experts to guide actions

Following their respective experts' advice, Sweden implemented pandemic vaccination for the general population while Denmark implemented a targeted policy of vaccinating about twenty percent of the population. 
tury. Naturally, the new pandemic will produce new empirical evidence that will allow us to revisit and nuance themes and findings of this article. From the face of it (we have yet to engage in a thorough analysis), it does appear that the central tenets of this article are supported by the recent developments. Covid-19 unequivocally puts to rest the question of whether pandemics can be securitized. Almost all political leaders have framed the pandemic as an existential threat, the public has broadly accepted this framing, and governments have implemented the most extraordinary measures seen in peace time. However, this article went further and discussed a certain type of securitization: expert-led securitization. Experts undoubtedly play significant roles in the policy stream in the present situation. But the scope of the pandemic has also forced politicians to take more active roles in many countries. Such more complex securitization processes only underline the importance of addressing the administrative processes of securitization when trying to explain the plethora of different strategies that have resulted from rather similar securitization framings. Returning to the case-countries in this article, Denmark appeared to follow a mixed securitization process where politicians and experts both had prominent roles. Sweden appeared more unique because its politicians explicitly left Covid-19 policymaking to the experts thereby displaying a high degree of expert-led securitization. We are hopeful that more comparative research on this topic will soon emerge, and that the new pandemic will spur greater interest in the process of securitization.

\section{Acknowledgments}

The idea of this article came out of a funding collaboration between the authors and Karen Lund Petersen and Olaf Corry at the Centre for Advanced Security Theory, University of Copenhagen. We want to thank Karen and Olaf for some excellent brainstorming sessions that laid a strong foundation for the present article. We are also grateful for comments we received when presenting a preliminary outline of this article at The Third Northern European Conference on Emergency and Disaster Studies in Amsterdam, 21-23 March 2018. Lastly, we want to thank the Academic Editors and the two anonymous reviewers for excellent comments and suggestions for improvements.

\section{Conflict of Interests}

The authors declare no conflict of interests.

\section{References}

Abraham, T. (2011). The chronicle of a disease foretold: Pandemic H1N1 and the construction of a global health security threat. Political Studies, 59(4), 797-812.
Altman, D. (2003). AIDS and security. International Relations, 17(4), 417-427.

Baekkeskov, E. (2016a). Same threat, different response: Experts steering politicians and stakeholders in 2009 H1N1 vaccination policy-making. Public Administration, 94(2), 299-315.

Baekkeskov, E. (2016b). Explaining science-led policymaking: Pandemic deaths, epistemic deliberation and ideational trajectories. Policy Sciences, 49(4), 395-419.

Baekkeskov, E., \& Öberg, P. (2017). Freezing deliberation through public expert advice. Journal of European Public Policy, 24(7), 1006-1026.

Baekkeskov, E., \& Rubin, O. (2014). Why pandemic response is unique: Powerful experts and hands-off political leaders. Disaster Prevention and Management, 23(1), 81-93.

Balzacq, T. (2005). The three faces of securitization: Political agency, audience and context. European Journal of International Relations, 11(2), 171-201.

Balzacq, T. (Ed.). (2010). Securitization theory: How security problems emerge and dissolve. Abingdon: Routledge.

Balzacq, T., \& Guzzini, S. (2015). Introduction: What kind of theory-if any-is securitization? International Relations, 29(1), 97-102.

Barfoed, C. (2009, April 28). Danskere kan dø i tusindvis [Danes can die in their thousands]. BT Newspaper. Retrieved from https://www.infomedia.dk

Bengtsson, L., \& Rhinard, M. (2019). Securitisation across borders: The case of 'health security' cooperation in the European Union. West European Politics, 42(2), 346-368.

Boin, A., McConnell, A., \& Hart, P. (2008). Governing after crisis: The politics of investigation, accountability and learning. New York, NY: Cambridge University Press.

Boswell, C. (2009). The political uses of expert knowledge: Immigration policy and social research. Cambridge: Cambridge University Press.

Buzan, B. (1997). Rethinking security after the Cold War. Cooperation and Conflict, 32(1), 5-28.

Buzan, B., Wæver, O., \& De Wilde, J. (1998). Security: A new framework for analysis. Boulder, CO: Lynne Rienner Publishers.

Curley, M. G., \& Herington, J. (2011). The securitisation of avian influenza: International discourses and domestic politics in Asia. Review of International Studies, 37(1), 141-166.

Davies, S. E. (2008). Securitizing infectious disease. International Affairs, 84(2), 295-313.

De Bengy Puyvallée, A., \& Kittelsen, S. (2019). Disease knows no borders: Pandemics and the politics of global health security. In K. Bjørkdahl \& B. Carlsen (Eds.), Pandemics, publics, and politics (pp. 59-73). Singapore: Palgrave Pivot.

Diez, T., Von Lucke, F., \& Wellmann, Z. (2016). The securitisation of climate change: Actors, processes and consequences. Abingdon: Routledge. 
Elbe, S. (2009). Virus alert: Security, governmentality, and the AIDS pandemic. New York, NY: Columbia University Press.

Elbe, S. (2011). Pandemics on the radar screen: Health security, infectious disease and the medicalisation of insecurity. Political Studies, 59(4), 848-866.

Elbe, S. (2012). Bodies as battlefields: Toward the medicalization of insecurity. International Political Sociology, 6(3), 320-322.

Enemark, C. (2017). Ebola, disease-control, and the Security Council: From securitization to securing circulation. Journal of Global Security Studies, 2(2), 137-149.

Eriksson, J. (1999). Debating the politics of security studies: Response to Goldmann, Wæver and Williams. Cooperation and Conflict, 34(3), 345-352.

Esping-Andersen, G. (2015). Welfare regimes and social stratification. Journal of European Social Policy, 25(1), 124-134.

Hall, P. A., \& Soskice, D. (2003). Varieties of capitalism and institutional complementarities. In R. Franzese, P. Mooslechner, \& M. Schürz (Eds.), Institutional conflicts and complementarities (pp. 43-76). Boston, MA: Springer.

Hameiri, S. (2014). Avian influenza, 'viral sovereignty,' and the politics of health security in Indonesia. The Pacific Review, 27(3), 333-356.

Hanrieder, T., \& Kreuder-Sonnen, C. (2014). World Health Organization decides on the exception? Securitization and emergency governance in global health. Security Dialogue, 45(4), 331-348.

Hood, C. (2010). The blame game: Spin, bureaucracy, and self-preservation in government. Princeton, NJ: Princeton University Press.

Howell, A. (2014). The global politics of medicine: Beyond global health, against securitisation theory. Review of International Studies, 40(5), 961-987.

Kamradt-Scott, A., \& Lee, K. (2011). The 2011 pandemic influenza preparedness framework: Global health secured or a missed opportunity? Political Studies, 59(4), 831-847.

Kingdon, J. W. (2014). Agendas, alternatives, and public policies: Updated 2nd edition. Essex: Pearson Education Limited.

Kittelsen, S. (2013). The EU and the securitization of pandemic influenza (Doctoral dissertation). Aberystwyth University, Aberystwyth, UK.

McDonald, M. (2008). Securitization and the construction of security. European Journal of International Relations, 14(4), 563-587.

McInnes, C., \& Lee, K. (2006). Health, security and foreign policy. Review of International Studies, 32(1), 5-23.

McInnes, C., \& Rushton, S. (2013). HIV/AIDS and securitization theory. European Journal of International Relations, 19(1), 115-138.

Moynihan, D. P. (2012). Extra-Network organizational reputation and blame avoidance in networks: The Hurricane Katrina example. Governance, 25(4), 567-588.
Myndigheten för Samhällsskydd och Beredskap. (2011). Influensa A (H1N1) 2009: Utvardering av forberedelser och hantering av pandemin [Evaluation of the preparation and management of the pandemic]. Stockholm: Myndigheten för Samhällsskydd och Beredskap and Socialstyrelsen.

Przeworski, A., \& Teune, H. (1970). The logic of comparative social inquiry. New York, NY: John Wiley.

Robinson, C. (2017). Tracing and explaining securitization: Social mechanisms, process tracing and the securitization of irregular migration. Security Dialogue, 48(6), 505-523.

Roemer-Mahler, A., \& Elbe, S. (2016). The race for Ebola drugs: Pharmaceuticals, security and global health governance. Third World Quarterly, 37(3), 487-506.

Rubin, O. (2020). The political dynamics of voter retrospection and disaster responses. Disasters, 44(2), 239-261.

Socialstyrelsen. (2006). Beredskapsplanering för en pandemisk influensa: Nationella insatser [Contingency planning for a pandemic influenza: National efforts]. Stockholm: Socialsstyrelsen.

Stritzel, H. (2007). Towards a theory of securitization: Copenhagen and beyond. European Journal of International Relations, 13(3), 357-383.

Sundhedsstyrelsen. (2006). Beredskab for pandemisk influenza: National strategi og rammer for planlægning i sundhedsberedskabet [Pandemic influenza preparedness: National strategy and framework for planning in health preparedness]. Copenhagen: Sundhedsstyrelsen.

Sundhedsstyrelsen. (2011). Redegørelse: Prioritering af pandemivacciner 2009 [Report: Prioritization of pandemic vaccines 2009]. Copenhagen: Sundhedsstyrelsen.

Sveriges Television. (2009a, April 28). Hälsoministern: Sverige har högsta beredskap. [Minister of Health: Sweden has the highest level of preparedness]. SVT Nyheter. Retrieved from https://www.svt.se/ nyheter/inrikes/halsoministern-sverige-har-hogstaberedskap

Sveriges Television. (2009b, June 11). Nya svininfluensan nu en pandemi. [The new swineflu is not a pandemic]. SVT Nyheter. Retrieved from https://www. svt.se/nyheter/inrikes/svininfluensan-nu-pandemi

Vilhelmsson, A., \& Mulinari, S. (2018). Pharmaceutical lobbying and pandemic stockpiling of Tamiflu: A qualitative study of arguments and tactics. Journal of Public Health, 40(3), 646-651.

Wæver, O. (1995). On security, securitization and desecuritization. New York, NY: Ronnie D. Lipschutz.

Watterson, C., \& Kamradt-Scott, A. (2016). Fighting flu: Securitization and the military role in combating influenza. Armed Forces \& Society, 42(1), 145-168.

Williams, M. C. (2015). Securitization as political theory: The politics of the extraordinary. International Relations, 29(1), 114-120.

World Health Organization. (2007). The world health re- 
port 2007: A safer future: global public health security in the 21st century. Geneva: World Health Organization. Retrieved from https://www.who.int/whr/ 2007/whr07_en.pdf?ua=1

World Health Örganization. (2011, April 21). Global vaccine safety: Statement on narcolepsy and vaccination [Press release]. Retrieved from https://www. who.int/vaccine_safety/committee/topics/influenza/ pandemic/h1n1_safety_assessing/narcolepsy_ statement/en

\section{About the Authors}

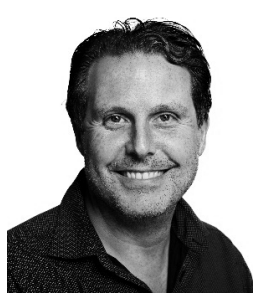

Olivier Rubin is Professor at the Department of Social Sciences and Business, Roskilde University, and a Member of the Executive Board at the Copenhagen Center for Disaster Research. He has 15 years of experience in disaster and health crisis resarch with a focus on the political and bureaucratic dynamics of slow-onset disasters such as famines, climate-induced disasters, pandemics and antimicrobial resistance. Rubin has published widely in international outlets pertaining to disasters, politics and development.

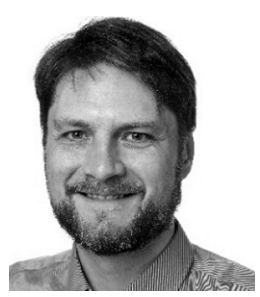

Erik Bækkeskov is Senior Lecturer in Public Policy at the School of Social and Political Science, University of Melbourne. His research focuses on public policymaking and politics related to infectious diseases such as the 2009 H1N1 influenza pandemic, the 2014 Ebola epidemic in West Africa, and the ongoing global antimicrobial resistance crisis. Baekkeskov has published widely in leading academic public policy and public administration outlets. 